\title{
Kebijakan Perlindungan Anak: Persepsi Orang Tua Suku Bajo Terhadap Kebijakan Gizi Seimbang Bagi Anak Remaja
}

\author{
Ruslan Halifu, R. Nunung Nurwati ${ }^{2}$, Binahayati Rusyidi ${ }^{3}$, Santoso Tri Raharjo ${ }^{4}$ \\ ${ }^{I}$ Program Studi Ilmu Kesejahteraan Sosial, Universitas Padjadjaran, Indonesia \\ ${ }^{2}$ Program Studi Ilmu Kesejahteraan Sosial, Universitas Padjadjaran, Indonesia \\ ${ }^{3}$ Program Studi Ilmu Kesejahteraan Sosial, Universitas Padjadjaran, Indonesia \\ ${ }^{4}$ Program Studi Ilmu Kesejahteraan Sosial, Universitas Padjadjaran, Indonesia
}

\section{ARTICLE INFORMATION}

Received: July 20, 2020

Revised: October 26, 2020

Accepted: November 01, 2020

Available online: November 07, 2020

\section{KEYWORDS}

Bajo, Nutrition, Perception, Policy, Teenager

\section{CORRESPONDENCE}

Phone: 085241754621

E-mail: ruslan17001@mail.unpad.ac.id ruslanhalifu@poltekbaubau.ac.id

\section{A B S T R A C T}

This study aims to find out perception of Bajo parents who has teenager (in Bajo Bahari Village, Wabula District, Buton Regency, Southeast of Sulawesi) to balanced nutrition policy and to find out relation of it perception. This study using a quantitatif method. The responden of this study is mothers of teenager in Bajo Bahari Village. The responden of this study selected under purposively sampling technique. The instrument of this study is the questionnaire. The data obtained were analyzed using SPSS program. The results showed that $83 \%$ respondents has perception to balanced nutrition policy is negative and $17 \%$ respondents has perception to it policy is positive. It caused by their knowledge about balanced nutrition that less. This study given scientific information that community who has perception to balanced nutrition that negative still available until now. They usually have the culture that unique, as example is Bajo Tribe in Bajo Bahari Village.

\section{PENDAHULUAN}

Masa remaja merupakan masa transisi (antara masa kanakkanak dan masa dewasa) yang dialami oleh setiap anak. Setiap anak yang berada pada usia 12 - 18 tahun maka ia dapat dikategorikan sebagai anak remaja (Santrock, 2012). Permulaan masa tersebut ditandai dengan adanya perubahan hormonal dan perubahan organ seks sekunder pada tubuh seseorang (Sacharin, 1994). Perubahan hormonal tersebut berkaitan dengan pertumbuhan ciri-ciri seks primer. Pertumbuhan ciri-ciri seks primer pada anak remaja ditandai dengan adanya peristiwaperistiwa (kejadian) biologis yang dialami oleh anak. Kejadian tersebut mencakup kejadian mimpi basah pada anak laki-laki dan menarche (menstruasi pertama) pada anak perempuan. Adapun perubahan organ seks sekunder pada anak remaja lakilaki meliputi: adanya perubahan suara, tumbuhnya kumis, tumbuhnya jakun dan tumbuhnya rambut di sekitar organ reproduksi bagian luar. Sedangkan perubahan organ seks sekunder pada anak remaja perempuan meliputi: bertambahnya ukuran pinggul, bertambahnya ukuran payudara dan tumbuhnya rambut di sekitar organ reproduksinya. Pada masa remaja juga terjadi peningkatan massa tubuh (tanpa lemak), massa tulang dan lemak tubuh (Fikawati et al., 2017). Selain itu, masa remaja juga dapat didefinisikan sebagai masa dimulainya seseorang berpikir kritis dan logis sehingga pada masa tersebut sangat baik untuk dimulainya pengembangan bakat, kemampuan dan minat seorang anak (Willis, 2017). Dari perubahan-perubahan tersebut, dapat dikatakan bahwa masa remaja merupakan masa kritis dalam kehidupan seseorang.
Untuk menunjang agar perubahan fisik anak remaja dapat berlangsung secara normal dan optimal, sangat diperlukan asupan zat gizi dalam tubuh yang memadai (Notoatmodjo, 2014). Sehingga asupan zat gizi anak remaja harus tetap terjaga. Pada tahun 1989 silam telah lahir suatu kesepakatan internasional yakni Convention on the Rights of the Child (CRC) atau Konvensi Hak Anak (KHA), dimana dalam kesepakatan tersebut terdapat berbagai hak anak remaja yang harus dipenuhi. Hak tersebut mencakup 4 (empat) kategori besar yakni hak kelangsungan hidup, hak perkembangan, hak perlindungan dan hak partisipasi (Castro et al., 2005). Adapun penjabarannya adalah: 1). Hak kelangsungan hidup. Seorang anak harus memperoleh sebuah nama, kewarganegaraan, keluarga, makanan, tempat tinggal, pakaian dan obat-obatan, dengan baik; 2). Hak perkembangan. Anak harus dapat mengembangkan semua aspek keberadaan mereka yakni aspek mental, aspek spiritual, aspek fisik dan aspek emosional atau psikologis, dengan baik; 3). Hak perlindungan. Anak harus mendapatkan perlindungan saat terjadinya perang serta harus mendapatkan perlindungan dari segala bentuk kekerasan dan eksploitasi; 4). Hak patisipasi. Anak harus mendapatkan akses ke informasi, akses ke tempat-tempat tertentu guna mengekspresikan pendapatnya dan untuk mengkonsultasikan berbagai hal-hal yang secara langsung mempengaruhi kehidupannya baik di tingkat keluarga, sekolah, tempat peribadatan dan masyarakat luas.

Berbagai penelitian terdahulu telah membahas tentang kebijakan yang berkaitan dengan hak anak remaja, di antaranya 
adalah kebijakan pengentasan masalah penggunaan narkoba pada anak remaja (Feinstein et al., 2012), kebijakan penanggulangan kebiasaan mengkonsumsi alkohol pada anak remaja (Bendtsen et al., 2014), kebijakan penanggulangan kebiasaan merokok pada anak remaja (Lovato et al., 2010), kebijakan pemberian tablet FE (Lestari et al., 2016), kebijakan penanggulangan penyakit anemia pada anak remaja (Kumari et al., 2017), kebijakan pusat konseling anak remaaj (Rachman, 2019), kebijakan program kesehatan reproduksi remaja (Pesiwarissa et al., 2019), kebijakan pemidanaan pada anak remaja (Sani, 2015). Kehadiran berbagai penelitian tersebut menambah referensi tentang kebijakan penyelesaian masalah anak. Namun, penelitian yang mengkaji tentang kebijakan gizi seimbang pada anak remaja masih belum ada.

Pada kenyataannya asupan zat gizi anak remaja masih selalu menjadi problem di tengah masyarakat hingga saat ini. Problem tersebut terjadi hampir di semua negara di dunia, sehingga problem tersebut dijadikan sebagai agenda prioritas di berbagai negara (Zare et al., 2017). Berbagai penyakit bisa ditimbulkan akibat masalah gizi, salah satu di antaranya adalah anemia. Di India, 55,8 \% dari jumlah anak remaja menderita anemia (UNICEF, 2010). Di Indonesia, asupan zat gizi juga masih menjadi suatu problem sosial, seperti: masih adanya anak remaja yang menderita anemia (Kemenkes RI, 2018) dan ukuran tubuh yang pendek atau abnormal. Anak remaja laki-laki cenderung makan lebih banyak sehingga secara tidak sadar ia akan dapat memenuhi kebutuhan gizinya, sedangkan anak remaja perempuan lebih berkonsentrasi menjaga berat badannya agar tetap terlihat proporsional (Fikawati et al., 2017). Sehingga risiko anak remaja perempuan untuk menderita kekurangan gizi cukup tinggi jika dibandingkan dengan anak remaja laki-laki.

Untuk mengatasi problem tersebut dan sekaligus sebagai bentuk kepatuhan terhadap CRC, pemerintah Indonesia telah mengeluarkan berbagai kebijakan. Salah satu kebijakan tersebut adalah kebijakan gizi seimbang bagi anak remaja sebagaimana yang diamanatkan oleh Undang-Undang Nomor 35 Tahun 2014 tentang Perlindungan Anak. Undang-Undang tersebut merupakan perubahan dari Undang-Undang Nomor 23 Tahun 2002. Dalam kebijakan gizi seimbang tersebut, setiap anak termasuk anak remaja harus diberikan makanan dengan menu seimbang

Lahirnya kebijakan tersebut di atas dapat menunjukkan bahwa asupan zat gizi memiliki keterkaitan dengan ketersediaan menu makanan. Hal tersebut sejalan dengan pernyataan Fikawati et al. (2017) bahwa asupan zat gizi dalam tubuh seseorang bersumber dari makanan yang ia konsumsi. Asupan zat gizi yang diperoleh anak remaja sangat bergantung pada menu makanan yang ia peroleh setiap hari. Idealnya, anak remaja harus mengkonsumsi berbagai makanan yang mengandung protein, lemak, karbohidrat, serat, vitamin dan mineral, yang cukup (Kemenkes RI, 2013). Hal tersebut disebabkan karena pada masa remaja, kebutuhan tubuh akan protein, lemak, karbohidrat, serat, vitamin dan mineral cukup tinggi dan dapat dikatakan bahwa volumenya merupakan yang tertinggi jika dibandingkan dengan masa kehidupan anak lainnya (seperti: bayi, balita dan masa sekolah dasar).

Pemenuhan hak anak merupakan tugas bersama antara pemerintah, keluarga dan masyarakat (Djusfi, 2019; Safrida \& Maulida, 2020). Negara harus memberikan fasilitas dan jaminan kepada setiap keluarga agar ia dapat menjalankan fungsinya sebagai penanggung jawab utama dalam pemenuhan hak-hak anaknya termasuk dalam memperoleh gizi yang seimbang. Menurut Tisak et al. (2017), keluarga merupakan unit terkeci dalam lingkungan sosial yang sangat mempengaruhi kualitas hidup anak sehingga perannya sangat penting dalam kehidupan anak. Selain itu, keluarga juga merupakan lingkungan yang paling dekat dengan anak. Dalam lingkungan keluarga, orang yang menjadi penanggung jawab utama adalah orang tua, sedangkan anak hanyalah sebagai anggotanya.

Umumnya, orang tua akan menjalankan perannya sesuai dengan persepsinya. Sebagaimana yang dikemukakan oleh Notoatmodjo (2014), persepsi merupakan salah satu dasar pembentukan sebuah perilaku dan persepsi tersebut juga dipengaruhi oleh proses kognitif atau pengetahuan. Sementara pengetahuan pada hakikatnya diperoleh seseorang setelah ia melakukan penginderaan baik melalui penglihatan, pendengaran, penciuman, rasa dan raba, terhadap suatu objek (Notoatmodjo, 2014). Dengan demikian, peran ataupun perilaku yang dilakukan oleh orang tua memiliki keterkaitan dengan persepsi dan pengetahuan yang dimiliki oleh orang tua tersebut.

Dalam implementasi kebijakan gizi seimbang bagi anak remaja, orang tua diberikan tugas agar senantiasa memberikan makanan dengan menu seimbang kepada anak remajanya. Dalam menjalankan peran tersebut, pemerintah akan memberikan pendidikan atau informasi kepada keluarga melalui berbagai program, di antaranya: melalui program posyandu, bina keluarga remaja dan kampung KB. Pola kerjasama tersebut telah diaktualisasikan hingga saat ini di berbagai daerah. Salah satu daerah yang dijadikan sebagai tempat aktualisasi dari pola kerja sama tersebut adalah Desa Bajo Bahari yang berada di Kecamatan Wabula, Kabupaten Buton, Sulawesi Tenggara. Daerah tersebut dihuni oleh masyarakat yang merupakan Suku Bajo. Suku tersebut memilliki lokasi pemukiman yang khas yakni berada di atas air laut. Sehingga sebagian besar aktivitas mereka dilakukan di atas air laut. Mereka memandang laut sebagai sahabat mereka. Berdasarkan studi pendahuluan, masyarakat Suku Bajo memiliki budaya yang khas. Kekhasan tersebut melekat pada sebagian besar aktivitas yang mereka jalankan setiap hari. Menurut Ranjabar (2006), masyarakat yang memiliki budaya yang khas akan sulit menerima konsep/kebijakan baru karena umumnya mereka memiliki persepsi tertentu pula. Penerimaan individu terhadap suatu kebijakan juga dapat dipengaruhi oleh persepsinya terhadap kebijakan tersebut (Ilhamsyah et al., 2020). Dalam hal masyarakat Suku Bajo, Persepsi tersebut dapat didasari oleh pengetahuan yang juga dimiliki oleh orang tua. Keadaan tersebut sering menjadi tantangan bagi penanggung jawab kebijakan (pemerintah) dalam menerapkan kebijakannya (Roscoe, 2012).

Karena berbagai alasan yakni: penelitian tentang kebijakan gizi seimbang pada anak remaja belum pernah dilakukan sebelumnya, masyarakat Desa Bajo Bahari termasuk masyarakat yang memiliki budaya khas, peluang keberhasilan penerapan kebijakan gizi seimbang bagi anak remaja yang telah berjalan di desa tersebut perlu dilihat dan peran orang tua sangat penting dalam penerimaan kebijakan tersebut, maka perlu dilakukan kajian atau penelitian terkait persepsi orang tua Suku Bajo yang memiliki anak remaja (di Desa Bajo Bahari, Kecamatan Wabula, Kabupaten Buton, Sulawesi Tenggara) terhadap kebijakan gizi seimbang bagi anak remaja dan keterkaitannya dengan pengetahuan orang tua. Adapun yang menjadi pertanyaan dari penelitian ini adalah bagaimana persepsi orang tua Suku Bajo yang memiliki anak remaja (di Desa Bajo Bahari, Kecamatan 
Wabula, Kabupaten Buton, Sulawesi Tenggara) terhadap kebijakan gizi seimbang bagi anak remaja dan bagaimana pula keterkaitannya dengan pengetahuan orang tua tersebut Oleh karena itu, tujuan dari penelitian ini adalah untuk mengetahui persepsi orang tua Suku Bajo yang memiliki anak remaja (di Desa Bajo Bahari, Kecamatan Wabula, Kabupaten Buton, Sulawesi Tenggara) terhadap kebijakan gizi seimbang bagi anak remaja dan untuk mengetahui keterkaitannya dengan pengetahuan orang tua tersebut.

\section{METODE}

Penelitian ini merupakan penelitian yang menggunakan metode kuantitatif, dengan pendekatan deskriptif. Tujuan pendekatan deskriptif adalah untuk membuat gambaran atau deskripsi tentang suatu keadaan atau suatu wilayah tertentu secara objektif, sistematis dan akurat (Sulistyaningsih, 2011). Metode tersebut dipilih karena penelitian ini akan melihat/mengukur gambaran persepsi orang tua Suku Bajo yang memiliki anak remaja (di Desa Bajo Bahari, Kecamatan Wabula, Kabupaten Buton, Sulawesi Tenggara) terhadap kebijakan gizi seimbang bagi anak remaja sekaligus beserta pengetahuannya, secara numerik. Sampel (responden) dalam penelitian ini adalah semua orang tua yang memiliki anak remaja di Desa Bajo Bahari. Batasan remaja tersebut adalah anak yang berumur 12 - 18 tahun. Berdasarkan pada data dari pemerintah desa, jumlah anak remaja yang ada di Desa Bajo Bahari adalah 76 orang. Orang tua yang dijadikan sampel dalam penelitian ini adalah ibu dari anak remaja tersebut, yang berjumlah 58 orang. Oleh karena itu, penelitian ini menggunakan teknik sampling berupa purposive sampling, yaitu menjadikan semua populasi sebagai sampel penelitian (Sulistyaningsih, 2011).

Prosedur penelitian ini sebagaimana yang dikemukakan oleh Sulistyaningsih (2011), diawali dengan studi pendahuluan. Studi tersebut dilakukan untuk melihat gambaran sosial budaya masyarakat secara umum. Gambaran tersebut mencakup: data distribusi anak remaja, keadaan budaya masyarakat secara umum dan gambaran kebijakan publik yang telah ada di tengah masyarakat. Informasi tersebut diperoleh dengan cara mengamati data induk penduduk desa (dokumentasi) dan melakukan interview kepada pemerintah desa setempat (Kepala Desa Bajo Bahari). Semua informasi tersebutlah yang menjadi bahan untuk studi pendahuluan. Kemudian studi pendahuluan tersebutlah yang memperkuat alasan pelaksanaan penelitian ini.

Penelitian ini berjalan dengan bantuan intrumen penelitian berupa kuesioner. Kuesioner tersebut berisikan pernyataanpernyataan yang berkaitan dengan persepsi orang tua terhadap kebijakan gizi seimbang bagi anak remaja. Setiap pernyataan diberikan pilihan berupa Sangat Setuju (SS), Setuju (S), Tidak Setuju (TS) dan Sangat Tidak Setuju (STS) yang masing-masing memiliki skor yang berbeda-beda. Menurut bentuknya, pernyataan-pernyataan tersebut terdiri atas 2 (dua) yakni pernyataan yang positif dan pernyataan yang negatif. Untuk pernyataan positif: jika responden memilih SS maka skornya adalah 4 (empat), jika responden memilih $S$ maka skornya adalah 3 (tiga), jika responden memilih TS maka skornya adalah 2 (dua) dan jika responden memilih STS maka skornya adalah 1 (satu). Sedangkan untuk pernyataan negatif: jika responden memilih SS maka skornya adalah 1 (satu), jika responden memilih S maka skornya adalah 2 (dua), jika responden memilih TS maka skornya adalah 3 (tiga) dan jika responden memilih STS maka skornya adalah 4 (empat). Skor-skor tersebut merupakan nilai yang diberikan secara objektif (berdasarkan teori) oleh peneliti terhadap pilihan yang telah dijawab oleh responden.

Sebagai variabel yang memiliki keterkaitan dengan terbentuknya persepsi, penelitian ini juga mengukur variabel tingkat pengetahuuan. Sehingga selain berisikan persepsi, kuesioner penelitian ini juga berisikan pernyataan-pernyataan yang berkaitan dengan pengetahuan orang tua tentang gizi seimbang bagi anak remaja (termasuk kebijakannya). Setiap pernyataan diberikan pilihan berupa Benar (B) dan Salah (S) yang masing-masing memiliki skor yang berbeda-beda. Sama halnya dengan pernyataan persepsi, pernyataan-pernyataan pengetahuan juga terdiri atas 2 (dua) yakni pernyataan yang positif dan pernyataan yang negatif. Untuk pernyataan positif: jika responden memilih B maka skornya adalah 1 (satu) dan jika responden memilih S maka skornya adalah 0 (nol). Sedangkan untuk pernyataan negatif: jika responden memilih B maka skornya adalah 0 (nol) dan jika responden memilih S maka skornya adalah 1 (satu). Skor-skor tersebut merupakan nilai yang diberikan secara objektif (berdasarkan teori) oleh peneliti terhadap pilihan yang telah dijawab oleh responden.

Setelah dihitung skor-skornya (persepsi dan pengetahuan) dan diperoleh hasilnya, maka variabel beserta kriteria objektifnya dan hasil hitungan skornya diinput ke dalam aplikasi SPSS (program pengolahan data). Kriteria objektif tersebut ditentukan sebelum penginputan. Untuk variabel persepsi, kriteria objektifnya terdiri atas dua bagian yaitu: positif dan negatif. Sedangkan untuk variabel pengetahuan, kriteria objektifnya terdiri atas dua bagian yaitu: baik dan kurang. Setelah penginputan selesai, dilanjutkan dengan tahapan analisis data. Analisis data tersebut juga dilakukan dengan bantuan aplikasi SPSS. Hasil analisisnya akan berupa tabel statistik (tabel distribusi frekuensi), dimana tabel tersebut berjumlah 2 (dua) buah yaitu: tabel statistik untuk persepsi orang tua Suku Bajo yang memiliki anak remaja (di Desa Bajo Bahari) terhadap kebijakan gizi seimbang bagi anak remaja dan tabel statistik pengetahuan orang tua Suku Bajo yang memiliki anak remaja (di Desa Bajo Bahari) tentang gizi seimbang bagi anak remaja (termasuk kebijakannya). Kedua tabel statistik tersebutlah yang akan dibandingkan dengan hipotesis penelitian ini. Adapun hipotesis penelitian ini adalah persepsi orang tua Suku Bajo yang memiliki anak remaja cenderung kurang baik atau negatif terhadap kebijakan gizi seimbang bagi anak remaja dan persepsi tersebut dipengaruhi oleh pengetahuan orang tua tentang gizi seimbang bagi anak remaja yang kurang baik atau rendah

\section{HASIL DAN PEMBAHASAN}

Masyarakat Suku Bajo dikenal sebagai manusia laut atau manusia perahu. Mereka menyebut diri mereka (termasuk Suku Bajo lainnya) dengan sebutan sama'. Sedangkan untuk orang lain (yang bukan merupakan Suku Bajo), Suku Bajo menyebutnya dengan istilah bagai. Dahulu, mereka tinggal di atas perahu biasa dan mereka hidup dengan mengembara/mengarungi lautan. Namun saat ini, karena kebutuhan dan perkembangan zaman, karakteristik tempat tinggal mereka menjadi ikut berubah. Mereka telah memilih untuk tinggal di rumah semi permanen (bukan lagi di perahu) dan letaknya berdekatan dengan pesisir pantai. Selain itu, masyarakat tersebut memiliki tempat tinggal yang saling berdekatan antara satu dengan yang lainnya. Meskipun demikian, ciri khas tempat tinggal mereka yang berada di atas air laut tidak pernah mengalami perubahan. 
Lokasi pemukiman Suku Bajo tersebar di berbagai daerah, di antaranya adalah di Provinsi Sulawesi Tenggara. Karena jumlah mereka yang semakin bertambah, biasanya mereka mengusulkan kepada pemerintah untuk membentuk sebuah desa sendiri. Salah satu desa yang dihuni oleh Suku Bajo adalah Desa Bajo Bahari yang tepatnya berada di Kecamatan Wabula, Kabupaten Buton, Provinsi Sulawesi Tenggara. Pada saat ini, berbagai kebijakan ataupun program pemerintah telah terlaksana di desa tersebut. Adapun contoh dari program tersebut adalah program kampung Keluarga Berencana (kampung KB), posyandu, dan sebagainya. Salah satu tujuan besar dari program-program tersebut adalah untuk menjadikan semua anak (termasuk anak remaja) menjadi tumbuh dan berkembang secara optimal dan mengupayakan/menjaga agar anak yang telah tumbuh dan berkembang secara optimal, tetap dalam keadaan stabil.

\section{Karakteristik Responden}

Berdasarkan data sekunder yang diperoleh dari pemerintah desa setempat, per tahun 2019 Desa Bajo Bahari dihuni oleh 76 orang anak remaja. Berdasarkan karakteristik umurnya, anak remaja di desa tersebut cukup bervariasi. Sebagian besar di antaranya berumur 15 - 18 tahun. Adapun data persebarannya dapat dilihat pada tabel berikut:

Tabel 1. Distribusi anak remaja di Desa Bajo Bahari menurut umur tahun 2019

\begin{tabular}{lll}
\hline Umur & Frekuensi & Persentase \\
\hline $12-14$ tahun & 34 orang & $45 \%$ \\
$15-18$ tahun & 42 orang & $55 \%$ \\
Total & 76 orang & $100 \%$ \\
\hline
\end{tabular}

Sumber: pemerintah Desa Bajo Bahari

Jika didasarkan pada karakteristik jenis kelamin anak remaja, sebagian besar anak remaja di Desa Bajo Bahari per tahun 2019 berjenis kelamin laki-laki. Adapun data persebarannya dapat dilihat pada tabel berikut:

Tabel 2. Distribusi anak remaja di Desa Bajo Bahari menurut jenis kelamin tahun 2019

\begin{tabular}{lll}
\hline Jenis Kelamin & Frekuensi & Persentase \\
\hline Laki-laki & 39 orang & $51 \%$ \\
Perempuan & 37 orang & $49 \%$ \\
Total & 76 orang & $100 \%$ \\
\hline
\end{tabular}

Sumber: Pemerintah Desa Bajo Bahari

\section{Persepsi Responden terhadap Kebijakan Gizi Seimbang bagi Anak Remaja}

Berdasarkan hasil temuan di lapangan, maka diperoleh hasil pengukuran tentang persepsi orang tua Suku Bajo yang memiliki anak remaja di Desa Bajo Bahari terhadap kebijakan gizi seimbang bagi anak remaja. Setelah melalui pengolahan dan analisa data, diperoleh hasil sebagaimana yang dapat dilihat pada tabel berikut:

Tabel 3. Distribusi tingkat persepsi responden terhadap kebijakan gizi seimbang bagi anak remaja

\begin{tabular}{lll}
\hline Tingkat Persepsi & Frekuensi & Persentase \\
\hline Positif & 10 orang & $17 \%$ \\
Negatif & 48 orang & $83 \%$ \\
Total & 58 orang & $100 \%$ \\
\hline
\end{tabular}

Sumber: data olahan hasil penelitian
Berdasarkan pada tabel 3, orang tua yang memiliki anak remaja di Desa Bajo Bahari cenderung memiliki persepsi yang negatif terhadap kebijakan gizi seimbang bagi anak remaja. Secara umum, dalam instrumen penelitian ini menanyakan persepsi orang tua terhadap muatan/isi dari kebijakan gizi seimbang bagi remaja dan manfaat dari kebijakan tersebut. Tingginya persepsi negatif tersebut dipengaruhi oleh faktor budaya. Pernyataan tersebut juga sejalan dengan pernyataan yang dikemukakan oleh Notoatmodjo (2014) bahwa persepsi seseorang dapat dibentuk/dipengaruhi oleh budaya yang dimilikinya. Menurut Koentjaraningrat (1990), budaya atau kebudayaan dapat didefinisikan sebagai hal-hal yang berhubungan dengan akal manusia.

Orang tua Suku Bajo yang memiliki anak remaja di Desa Bajo Bahari cenderung memandang bahwa menu makanan seimbang yang merupakan interpretasi dari Undang-Undang Nomor 35 Tahun 2014 kurang sesuai dengan kebiasaan mereka yang telah ada sejak dahulu kala. Interpretasi peraturan atau kebijakan tersebut menyebutkan bahwa anak remaja harus dipenuhi hakhaknya termasuk hak untuk memperoleh gizi seimbang. Gizi seimbang yang dimaksud berhubungan dengan makanan yang dikonsumsi oleh anak remaja setiap hari, yang idealnya harus mengandung karbohidrat, protein, lemak, vitamin dan mineral. Amanah dari kebijakan tersebutpun diperkuat dengan pedoman yang dikeluarkan dari Kemenkes RI (2013) yang mengatakan bahwa agar pertumbuhan dan perkembangan anak remaja berjalan dengan baik maka ia harus diberikan berbagai makanan yang mengandung protein, lemak, karbohidrat, serat, vitamin dan mineral, yang cukup (porsi seimbang). Kandungan makanan menjadi lebih penting karena sebagaimana yang dikemukakan oleh Fikawati et al. (2017) bahwa asupan zat gizi dalam tubuh seseorang bersumber dari makanan yang ia konsumsi setiap hari.

Sementara orang tua Suku Bajo yang memiliki anak remaja (di Desa Bajo Bahari) cenderung memandang bahwa makanan yang wajib ada dan dikonsumsi oleh anak remaja hanyalah mencakup nasi dan ikan. Berdasarkan kandungan gizinya, nasi mengandung karbohidrat dan ikan mengandung protein. Makanan lainnya, seperti sayur, buah ataupun daging hanyalah merupakan makanan pilihan. Bagi mereka, nasi dan ikan adalah bentuk kesederhanaan dalam pola hidup sehari-hari. Nenek moyang mereka telah mewariskan kepada mereka dan keturunan-keturunan selanjutnya untuk senantiasa hidup sederhana. Untuk menyediakan menu sayur ataupun menu makanan lainnya (selain nasi dan ikan) juga membutuhkan biaya yang relatif banyak. Hasil pendapatan mereka hanya diperuntukkan untuk membeli beras dan kebutuhan lainnya, sedangkan ikan tidak perlu dibeli karena dapat mereka peroleh sendiri dengan cara melaut. Pada zaman dahulu, ikan tersebut sekaligus juga menjadi alat pembayaran. Pada masa tersebut, ikan yang mereka peroleh ditukar dengan kebutuhan pokok lainnya milik masyarakat darat seperti beras, melalui sistem barter.

Nasi dan ikan dianggap sebagai menu wajib untuk makanan sehari-hari. Makanan akan terasa tidak sedap ataupun enak ketika tidak ada hidangan ikan. Orang tuapun senantiasa berupaya menyediakan hidangan ikan untuk anggota keluarganya termasuk anak remajanya, setiap hari. Selain itu, jika sehari saja mereka tidak mengkonsumsi ikan maka kepala mereka akan terasa sedikit sakit (pening). Bahkan kadangkadang mereka mengkonsumsi ikan tanpa nasi dan ikan tersebut masih dalam kondisi mentah (belum dimasak). Ikan tersebut 
hanya dipotong-potong (dicincang) kemudian dicampurkan dengan sedikit jeruk nipis. Suku Bajo menyebut makanan tersebut dengan istilah dayah dititta. Pola yang demikian telah ada sejak zaman nenek moyang mereka dan relatif kuat hingga saat ini. Sehingga karena budaya masyarakat Suku Bajo yang relatif kuat maka mereka memandang bahwa menu makanan yang senantiasa mereka berikan kepada anak remaja telah sesuai dengan kebutuhan pertumbuhan dan perkembangan anak remaja mereka.

Pada dasarnya kebijakan gizi seimbang yang merupakan interpretasi dari Undang-Undang Nomor 35 Tahun 2014 memiliki tujuan yang baik yakni untuk menjaga asupan gizi pada setiap anak termasuk anak remaja agar ia tidak mengalami kekurangan gizi dan pertumbuhan atau perkembangan fisik anak tersebut pun akan berlangsung secara normal atau optimal. Ketika pertumbuhan dan perkembangan anak berjalan dengan normal, maka anak tersebut akan dapat menjalankan tugastugas perkembangannya dengan baik. Selain itu, ketika pertumbuhan dan perkembangan anak berjalan dengan normal, maka kualitas hidup (kesejahteraan) anak tersebut akan terjamin (Apsari, 2015). Pemerintah memandang bahwa kualitas fisik anak sangatlah penting karena kualitas fisik anak akan ikut mempengaruhi kualitas mental dan sosialnya. Kualitas fisik anak yang tidak baik dapat menimbulkan berbagai masalah baru, seperti: stunting dan sebagainya. Ketika hal tersebut muncul, maka kemajuan bangsa dan negara di kemudian hari akan sulit terwujud karena pada dasarnya anak adalah generasi masa depan bangsa dan negara. Sehingga kebijakan pemerintah tentang gizi seimbang senantiasa didengungkan di berbagai program, seperti: pada pelaksanaan program Kampung Keluarga Berencana (Kampung KB) dan pada pelaksanaan program posyandu. Sementara sebagian besar orang tua Suku Bajo yang memiliki anak remaja (di Desa Bajo Bahari) memandang bahwa tujuan dari kebiasaan mereka adalah untuk memperkenalkan nilai-nilai budaya kepada anak remaja mereka dan nilai-nilai tersebut lebih penting dari pertumbuhan/perkembangan fisik anak. Pola yang demikian telah ada sejak zaman nenek moyang mereka dan relatif kuat hingga saat ini. Sehingga karena budaya masyarakat Suku Bajo yang relatif kuat maka mereka memandang bahwa kebiasaan yang senantiasa mereka lakukan telah memiliki tujuan yang lebih besar terhadap kehidupan anak.

Budaya Suku Bajo tentang menu makanan yang harus diberikan oleh orang tua kepada anak remajanya dan tentang tujuan dari kebiasaan tersebut, yang kurang sesuai dengan amanah dari kebijakan gizi seimbang kepada anak remajanya, pada akhirnya mengakibatkan persepsi sebagian besar orang tua yang memiliki anak remaja (di Desa Bajo Bahari) pun menjadi negatif dalam menanggapi kebijakan gizi seimbang. Pernyataan hasil tersebut sejalan dengan pernyataan yang dikemukakan oleh Ranjabar (2006), masyarakat yang memiliki budaya yang khas akan sulit menerima konsep/kebijakan baru karena umumnya mereka memiliki persepsi tertentu pula.

Selain karena faktor budaya, tingginya persepsi negatif orang tua yang memiliki anak remaja (di Desa Bajo Bahari) terhadap kebijakan gizi seimbang bagi anak remaja juga dipengaruhi/disebabkan oleh kurangnya pengetahuan mereka tentang kebijakan tersebut. Distribusi tingkat pengetahuan orang tua yang memiliki anak remaja di Desa Bajo Bahari (responden) tentang kebijakan gizi seimbang bagi anak remaja dapat dilihat pada tabel berikut:
Tabel 4. Distribusi tingkat pengetahuan responden tentang gizi seimbang bagi anak remaja

\begin{tabular}{lll}
\hline $\begin{array}{l}\text { Tingkat } \\
\text { Pengetahuan }\end{array}$ & Frekuensi & Persentase \\
\hline Baik & 10 orang & $17 \%$ \\
Kurang & 48 orang & $83 \%$ \\
Total & 58 orang & $100 \%$ \\
\hline
\end{tabular}

Sumber: data olahan hasil penelitian

Berdasarkan pada tabel 4, orang tua yang memiliki anak remaja di Desa Bajo Bahari cenderung memiliki pengetahuan tentang kebijakan gizi seimbang bagi anak remaja, yang kurang baik. Dengan demikian dapat dikatakan bahwa ketika pengetahuan seseorang tentang suatu objek dikategorikan rendah maka persepsinya terhadap kehadiran objek tersebutpun akan ikut rendah. Sebaliknya, ketika pengetahuan seseorang tentang suatu objek dikategorikan baik maka persepsinya terhadap kehadiran objek tersebutpun akan ikut baik. Pernyataan tersebut juga sejalan dengan pernyataan yang dikemukakan oleh Notoatmodjo (2014) bahwa persepsi seseorang dapat dibentuk/dipengaruhi oleh kualitas pengetahuannya.

\section{KESIMPULAN}

Berdasarkan hasil penelitian, orang tua Suku Bajo yang memiliki anak remaja (di Desa Bajo Bahari, Kecamatan Wabula, Kabupaten Buton, Sulawesi Tenggara) cenderung memiliki persepsi yang negatif terhadap kebijakan gizi seimbang bagi anak remaja yang telah dicanangkan oleh pemerintah sebagai amanah dari Undang-Undang Nomor 35 Tahun 2014 tentang perlindungan anak. Salah satu faktor yang menyebabkan persepsi orang tua tersebut menjadi negatif adalah karena rendahnya pengetahuan mereka tentang gizi seimbang (termasuk kebijakannya).

\section{REFERENSI}

Apsari, N. C. (2015). Hak Anak: PerspektifPekerjaan Sosial. UNPAD Press.

Bendtsen, P., Damsgaard, M. T., Huckle, T., Casswell, S., Kuntsche, E., Arnold, P., de Looze, M. E., Hofmann, F., Hublet, A., Simons-Morton, B., ter Bogt, T., \& Holstein, B. E. (2014). Adolescent alcohol use: A reflection of national drinking patterns and policy? Addiction, 109(11), 1857-1868. https://doi.org/10.11ll/add.12681

Castro, E. P.-D., Camacho, A. Z. V, Balanon, F. A. G., Yacat, J. A., Galang, M. T., \& Ong, M. G. (2005). Handbook for Social Workers on Basic Bio-Psychosocial Help for Children in Need of Special Protection. UNICEF.

Djusfi, A. R. (2019). Kedudukan Dan Fungsi Komisi Perlindungan Anak Indonesia Dalam Melindungi Hak-Hak Anak. Jurnal Public Policy, 2(2), 152-158. https://doi.org/10.35308/jpp.v2i2.763

Feinstein, E. C., Richter, L., \& Foster, S. E. (2012). Addressing the critical health problem of adolescent substance use through health care, research, and public policy. Journal of Adolescent Health, 50(5), 431-436. https://doi.org/10.1016/j.jadohealth.2011.12.033

Fikawati, S., Syafiq, A., \& Veratamala, A. (2017). Gizi Anak dan Remaja. PT RajaGrafindo Persada.

Ilhamsyah, F., Tjoetra, A., \& Ikhsan, I. (2020). Larangan 
Merokok di Mata Mahasiswa: Studi Tentang Kebijakan Larangan Merokok di Tempat Umum. Jurnal Public Policy, 6(1), 31-34. https://doi.org/10.35308/jpp.v6il.1610

John W. Santrock. (2012). LIFE-SPAN Development (13th ed.). In McGraw-Hill.

Kemenkes RI. (2013). Riset Kesehatan Dasar (Riskesdas) 2013. Kementerian Kesehatan Republik Indonesia.

Kemenkes RI. (2018). Riset Kesehatan Dasar (Riskesdas) 2018. Kementerian Kesehatan Republik Indonesia.

Koentjaraningrat. (1990). Pengantar Ilmu Antropologi. Rineka Cipta.

Kumari, R., Bharti, R. K., Singh, K., Sinha, A., Kumar, S., Saran, A., \& Kumar, U. (2017). Prevalence of iron deficiency and iron deficiency anaemia in adolescent girls in a tertiary care hospital. Journal of Clinical and Diagnostic Research, 11(8), 4-6. https://doi.org/10.7860/JCDR/2017/26163.10325

Lestari, P., Widardo, W., \& Mulyani, S. (2016). Pengetahuan Berhubungan dengan Konsumsi Tablet Fe Saat Menstruasi pada Remaja Putri di SMAN 2 Banguntapan Bantul. Jurnal Ners Dan Kebidanan Indonesia, 3(3), 145-149. https://doi.org/10.21927/jnki.2015.3(3).145-149

Lovato, C. Y., Zeisser, C., Campbell, H. S., Watts, A. W., Halpin, P., Thompson, M., Eyles, J., Adlaf, E., \& Brown, K. S. (2010). Adolescent smoking: Effect of school and community characteristics. American Journal of Preventive Medicine, 39(6), 507-514. https://doi.org/10.1016/j.amepre.2010.08.019

Notoatmodjo, S. 2014. I. P. K. J. R. C. (2014). Kesehatan Masyarakat Ilmu \& Seni. Jakarta: Rineka Cipta. In Rineka Cipta :Jakarta.

Pesiwarissa, P. E., Messakh, S. T., \& Panuntun, B. (2019). Gambaran Implementasi Program Kesehatan Reproduksi Remaja di Puskesmas Getasan. Jurnal Keperawatan Respati Yogyakarta, $\quad 6(2), \quad 570-574$. https://doi.org/10.35842/jkry.v6i2.314

Rachman, R. F. (2019). Implementasi Kebijakan Pusat Konseling Anak Dan Remaja Di Surabaya. Al-Tazkiah: Jurnal Bimbingan Dan $\quad$..., $\quad$ 8(2), 77-9l. https://journal.uinmataram.ac.id/index.php/altazkiah/articl e/view/1217

Ranjabar, J. (2006). Sistem Sosial Budaya Indonesia: Suatu Pengantar. Penerbit Ghalia Indonesia.

Roscoe, A. (2012). International Development Policy and Practice: The Translation of a Children's Rights-Based Approach. In ProQuest Dissertations and Theses. http://search.proquest.com.ezproxy.library.uvic.ca/docview /1034118623?accountid=14846\%0Ahttp://g5jh7pa3n.search. serialssolutions.com/directLink?\&atitle=International + Dev elopment+Policy+and+Practice $\% 3 \mathrm{~A}+$ The +Translation +of +a +Children $\% 27 \mathrm{~s}+$ Rights-Based+Approa

Sacharin, R. M. (1994). Prinsip Keperawatan Pediatrik. Penerbit Buku Kedokteran EGC.

Safrida, S., \& Maulida, D. (2020). Kebijakan Pemerintah dalam Menanggulangi Kekerasan Seksual Anak di Bawah Umur (Studi di Kabupaten Aceh Utara). Jurnal Public Policy, 6(1), 45-50. https://doi.org/10.35308/jpp.v6il.1765

Sani, A. (2015). Pemidanaan Anak Menurut Hukum Islam Dan Hukum Pidana Indonesia. Jurnal Public Policy, 1(1), 1-10. https://doi.org/10.35308/jpp.v0i0.702

Sulistyaningsih. (2011). Metodologi Penelitian: Kebidanan
(Kuantitatif-Kualitatif). Graha Ilmu.

Tisak, M. S., Tisak, J., Chen, Y., Fang, Q., \& Baker, E. R. (2017). Adolescent Misconduct Behaviors: A Cross-Cultural Perspective of Adolescents and Their Parents. Journal ofCrossCultural Psychology, 48(2), 155-167. https://doi.org/10.1177/0022022116681844

UNICEF. (2010). Progress for Children: A Report Card for Adolescents (Issue 9).

Willis, S. S. (2017). Remaja e Masalahnya. Penerbit Alfabeta.

Zare, E., Simbar, M., Shahhosseini, Z., \& Alavi Majd, H. (2017). The Priorities of Iranian Male Adolescents Health Needs. American Journal of Men's Health, 11(4), 1255-1259. https://doi.org/10.1177/1557988317693346 